\title{
Short Communication: Strong genetic differentiation of the endemic rosin-producing tree Styrax sumatrana (Styracaceae) in North Sumatra, Indonesia
}

\author{
HENTI HENDALASTUTI RACHMAT ${ }^{1, \nu}$, ARIDA SUSILOWATI ${ }^{2, \nu v}$, DENI ELFIATI ${ }^{2}$, KANSIH SRI HARTINI ${ }^{2}$, \\ WIZA NONI FARADILLAH \\ ${ }^{1}$ Forest Research and Development Center. Jl. Gunung Batu No. 5. PO Box 165, Bogor 16001, West Java, Indonesia. Tel.: +62-251-8633234; 7520067. \\ Fax. +62-251-8638111, `email: hendalastuti@yahoo.co.uk \\ ${ }^{2}$ Faculty of Forestry, Universitas Sumatera Utara. Jl. Tri Dharma Ujung No 1, Kampus USU, Medan 20155, North Sumatra, Indonesia. \\ Tel./Fax.: +62-61-8211633, ${ }^{\circ}$ email: arida iswanto@yahoo.co.id
}

Manuscript received: 6 Agustus 2017. Revision accepted: 25 August 2017.

\begin{abstract}
Rachmat HH, Susilowati A, Elfiati D, Hartini KS, Faradillah WN. 2017. Short Communication: Strong genetic differentiation of the endemic rosin-producing tree Styrax sumatrana (Styracaceae) in North Sumatra, Indonesia. Biodiversitas 18: 1331-1335. Styrax sumatrana is an economically important rosin-producing tree endemic to North Sumatra, Indonesia. Distribution of this species is very limited, and the high rate of forest degradation in Sumatra is increasing the necessity for conservation. To quantify genetic variation and population structuring, we collected individuals from 3 populations namely Pakpak Bharat, Humbang Hasundutan (Humbahas) and Tapanuli Utara in which each of the population was represented by 10 individuals. However, the successful rate of amplification was varied among populations and for later analysis, we only took an account those sequences showing clear electropherograms and disposed those which showed ambiguity. We sequenced $\operatorname{trnL-trnF}$ chloroplast DNA (cpDNA) region yielded 941 bp after alignment. The $\operatorname{trnL}$-trnF assigned the species into 4 haplotypes in which Pakpak Bharat was differentiated significantly and not shared any similar haplotypes with two others populations. Humbahas and Tapanuli Utara was shared one common haplotype. Mean nucleotide diversity at silent sites ranged $0-3.33 \times 10^{-3}$, while nucleotide diversity at non-synonymous site ranged $0-5.9 \times 10^{-4}$. Strong genetic differentiation was also found among 3 origin populations, with the highest pairwise genetic differentiation found on Pakpak Bharat and Tapanuli Utara $\left(\mathrm{F}_{\mathrm{ST}}=0.80952\right)$. Clear and apparent genetic structuring was possibly caused by geographical barriers such as highland and mountain ranges (Bukit Barisan mountain ranges) which acted as effective barriers to gene flow among population. The findings suggest that conservation efforts should focus on every population because each of the population maintains distinct genetic identity.
\end{abstract}

Keywords: $\operatorname{trnL}$-trnF, genetic diversity, Styrax sumatrana, genetic differentiation

\section{INTRODUCTION}

Styrax is a genus of about 130 species in the family Styracaceae with the major habitat in eastern and southeastern Asia. For local communities in North Sumatra, Indonesia, this rosin-producing tree has been an economically important commodity since centuries. The tree, locally known as kemenyan, has been cultivated in many localities including Tapanuli Utara, Dairi, Pakpak Bharat and Humbang Hasundutan (Humbahas). Statistical data (BPS 2008) showed that Tapanuli Utara owned the largest cultivated area covering $22.670 \mathrm{Ha}$ with the resin production of about $321,3 \mathrm{~kg} / \mathrm{ha} / \mathrm{yr}$ with total production of about 4.247 tones/yr. Humbahas District is also known to have huge kemenyan cultivation namely $9.594 \mathrm{Ha}$.

Styrax sumatrana is an economically important rosinproducing tree, endemic to North Sumatra, Indonesia and is locally known as kemenyan toba or haminjon (Lubis et al. 1984). In North Sumatra, this species has long been cultivated since 18 th century and economically important for local communities. Rosin from this family has long been known for medicinal, ritual, and pharmaceutical use and globally named benzoin resin. In pharmaceutical and medicinal preparation, it is used as an expectorant tincture for bronchitis and laryngitis, as an antiseptic to prevent infection and to cure stomachache and skin diseases (Burkill 1935; Katz et al. 2002). Later research found wider application and use of the resin, e.g to cure mastitis disease in dairy cattle (Mooventhan et al. 2016), to prevent cast slippage in cubfoot (Ibrahim 2016) and event to be patented as a trans-mucosal delivery of pharmacologically active agent (Battaglia and Beim 2016).

Sumatran rain forests were cleared and converted at an annual rate of 500,000 hectares or $2.56 \% \mathrm{yr}^{-1}$ and since 2011 it was listed as a site of World Heritage in Danger (Curran 2004; Gaveau 2009). Consequently, an emergency conservation plan is a priority. Through the economic benefit of the species, $S$. sumatrana (kemenyan Toba) has long been cultivated and this made the species gained more concern on conservation aspect. Local communities plant and cultivate the species on their private lands. This kind of cultivation usually develops the local kemenyan variant in each of the localities. Hence, there are several local names standing both for similar and different species of the Styrax, for example: kemenyan toba, kemenyan bulu, kemenyan batak, kemenyan durame, kemenyan minyak, and kemenyan dairi. Each shows slightly different morphological tree and resin characters. Even though for 
local communities there is clear separation of the kemenyan growing and planting in their gardens, genetic analysis for the separation of the species has not been reported before.

The chloroplast genome is considered a single, nonrecombining unit of inheritance and that is structurally stable (primarily maternally in angiosperms) (Olmstead and Palmer 1994; Birky 1995). Molecular marker-based genetic studies are crucial for elucidating appropriate management units for both conservation and production purposes. An understanding of genetic identity of the species and/or population is great practical importance both to conservation biologists and silviculturist. In the present study, we hypothesize that (i) since $S$. sumatrana is an endemic species and cultivated by localities with significant geographical barriers among localities, each locality or sub population will harbor distinct genetic identity; and (ii) as a result of significant geographic barriers, there will be strong genetic structure among population. We used trnL-trnF cpDNA region to address the objective of identifying the level of genetic variation and describing population differentiation among the populations of $S$. sumatrana and discussing the causes of shaping of the population genetic structure.

\section{MATERIALS AND METHODS}

\section{Plant material}

Sampling sites in North Sumatra, Indonesia were selected based on the existence and abundance of kemenyan toba cultivation, those including three districts of Pakpak Bharat, Tapanuli Utara and Humbang Hasundutan (Humbahas) with 10 productive trees which were sampled at each site (Figure 1). Here, productive trees refer to trees which, currently being tapped for resin, generally aged 15 years or more with the average diameter at breast height was $21 \mathrm{~cm}$. Sampled leaves were dried with silica gel and used for DNA extraction. Total genomic DNA was extracted from leaf samples using a modified CTAB method (Murray and Thompson 1980).

\section{DNA sequencing of trnL-trnF chloroplast DNA (cpDNA)}

trnL-trnF region was amplified by PCR using the universal $\mathrm{c}$ and $\mathrm{f}$ primers described in Taberlet et al. (1991). PCR was performed in $20 \mathrm{uL}$ of a solution containing $10 \mathrm{ng}$ of genomic DNA, five pmol of each forward and backward primer, and $10 \mathrm{uL}$ of Go Taq ${ }^{\circledR}$ Hot Start Colourless Master Mix (Promega, Wisconsin, USA) according to the manufacturer's instructions. Initial denaturation was performed at $95^{\circ} \mathrm{C}$ for $2 \mathrm{~min}$, followed by $30-35$ cycles of denaturation at $95^{\circ} \mathrm{C}$ for $1 \mathrm{~min}$, annealing

Table 1. Single nucleotide polymorphism found among $S$. sumatrana tree that divided the species into 4 distinct haplotypes

\begin{tabular}{lccccc}
\hline \multirow{2}{*}{ Haplotype } & \multicolumn{6}{c}{ Single Nucleotide Polymorphism at (bp) } \\
\cline { 2 - 6 } & $\mathbf{1 4 6}$ & $\mathbf{5 8 5}$ & $\mathbf{6 1 7}$ & $\mathbf{6 8 0}$ & $\mathbf{7 5 5}$ \\
\hline Haplotype I & $\mathrm{C}$ & $\mathrm{A}$ & $\mathrm{A}$ & $\mathrm{T}$ & $\mathrm{T}$ \\
Haplotype II & $\mathrm{A}$ & $\mathrm{A}$ & $\mathrm{A}$ & $\mathrm{T}$ & $\mathrm{T}$ \\
Haplotype III & $\mathrm{A}$ & $\mathrm{C}$ & $\mathrm{A}$ & $\mathrm{T}$ & $\mathrm{T}$ \\
Haplotype IV & $\mathrm{A}$ & $\mathrm{A}$ & $\mathrm{C}$ & $\mathrm{G}$ & $\mathrm{C}$ \\
\hline
\end{tabular}

at $50^{\circ} \mathrm{C}$ and polymerization at $72^{\circ} \mathrm{C}$ for $45 \mathrm{~min}$, and final extension at $72^{\circ} \mathrm{C}$ for $7 \mathrm{~min}$. Prior to sequencing, the PCR products were purified and automatic sequenced by Genetic Science (Singapore). DNA sequencing was performed for both strands with the primers were used for the PCR amplifications.

\section{Data analysis}

DNA sequences were checked visually and forward and backward traces were assembled using the ATGC program (Genetyx Corporation, Japan). Haplotype diversity and nucleotide diversity (Nei 1987) were calculated using DnaSP version 5.10 (Rozas et al. 2005) Tests of neutrality, Tajima's $D$ (1989), Fu and Li's $D^{*}$ and $F^{*}$ (1993), Fu's Fs (1997), and test of pairwise population differentiation were also performed using DnaSP.

\section{RESULTS AND DISCUSSION}

\section{Results}

Sequences of $941 \mathrm{bp}$ were determined after alignment with 5 segregating sites in all individuals. The $\operatorname{trnL}-\operatorname{trnF}$ region defined individuals into 4 haplotypes (Figure 1-2) (Table 1-2) in which haplotype 2 shared between Humbahas and Tapanuli Utara while the rest are distinct for each of the population. Pakpak Bharat population was assigned only into one distinct haplotype (Haplotype 3), while Tapanuli Utara consisted of two haplotypes (Haplotype 1 and 2) and Humbahas also consisted of two haplotypes (Haplotype 2 and 4). Genetic identity for each of population is shown in Table 3. Since Pakpak Bharat was only assigned into one haplotype, the numbers of nucleotide differences or also known as nucleotide diversity were 0.000 both for silent and non-synonymous sites. In Humbahas population, the mutation occurred in synonymous and non-coding with the nucleotide diversity at silent site $\left(\pi_{s}\right)$ was $2.67 \times 10^{-3}$ and $\theta$ value was $2.4 \times 10^{-3}$. Contrary to that of Humbahas, mutation in Tapanuli Utara population occurred at non-synonymous site with $\pi_{\text {non-syn }}$ was $1.25 \times 10^{-3}$ and $\theta$ value was $8.4 \times 10^{-3}$. The average number of nucleotide differences per silent sites $\left(\pi_{s}\right)$ in total populations was $3.33 \times 10^{-3}$ and $\theta$ value was $5.7 \times 10^{-4}$. Tajima's $D$ showed no significant results (Table 3 ) and neither did the other three neutrality tests (data not shown).

Pairwise population structure showed that population differentiation between Pakpak Bharat and two other populations were very high (Table 4), while Humbahas and Tapanuli Utara shared similar haplotypes and those showed weak population structuring.

Table 2. Sampling number per population and its successful amplification

\begin{tabular}{lcc}
\hline Population & Sample (N) & Successful amplification \\
\hline Pakpak Bharat & 10 & 10 \\
Humbahas & 10 & 6 \\
Tapanli Utara & 10 & 8 \\
Total & 30 & 24 \\
\hline
\end{tabular}




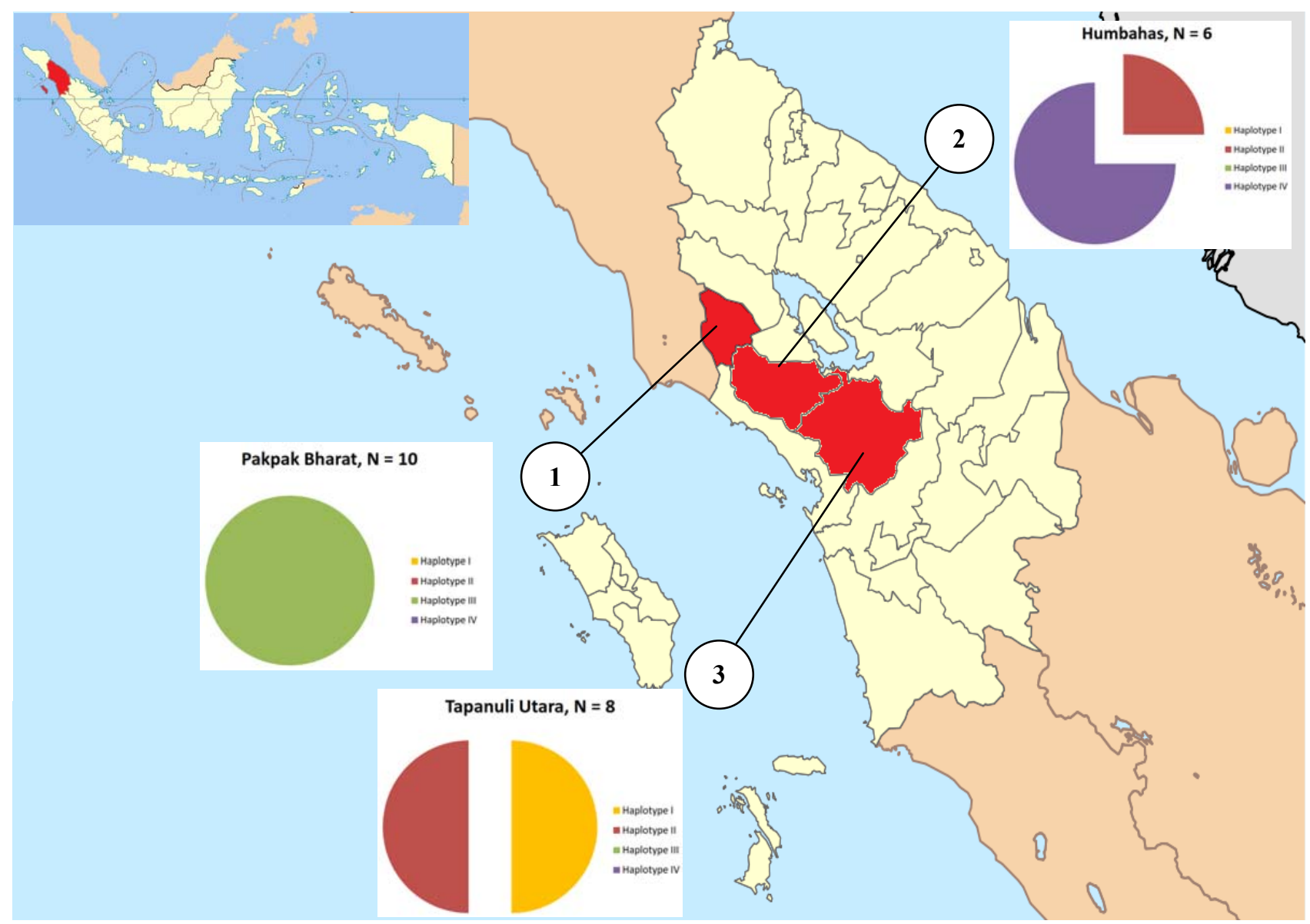

Figure 2. Haplotype assignment based on trnL-trnF cpDNA region among three population of S. sumatrana in North Sumatra, Indonesia. Note: 1. Pakpak Barat, 2. Humbang Hasundutan, 3. Tapanuli Utara
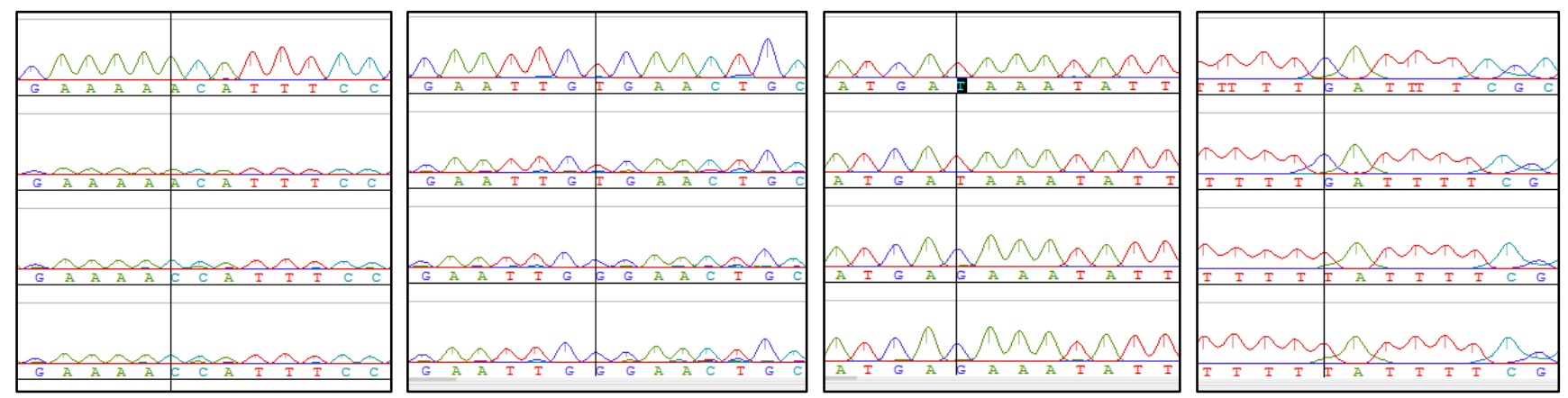

Figure 2. Sequences performance showing several segregating sites that divided the sequences into four haplotypes

Table 3. Nucleotide variation in S. sumatrana as inferred from trnL-trnF cpDNA regions

\begin{tabular}{llllllll}
\hline \multirow{2}{*}{ Pop. } & $\mathbf{L}$ & \multirow{N}{*}{$\boldsymbol{N}$} & $\boldsymbol{S}$ & \multirow{H}{*}{$\boldsymbol{(}\left(\times \mathbf{1 0}^{-3}\right)$} & \multirow{2}{*}{$\boldsymbol{\boldsymbol { \pi } _ { \boldsymbol { s } }}$} & $\boldsymbol{\theta}_{\boldsymbol{s}}$ & $\boldsymbol{D}$ \\
\hline Pakpak Bharat & 941 & 20 & 0 & 0.000 & 0.00 & 0.00 & na \\
Humbahas & 941 & 12 & 3 & 0.429 & 2.67 & 2.40 & 0.458 \\
Tapanuli Utara & 941 & 16 & 1 & 0.571 & 0.00 & 0.00 & 1.444 \\
Total & 941 & 48 & 4 & 0.751 & 3.33 & 2.18 & 1.212 \\
\hline
\end{tabular}

Length sequences aligned (L), population (Pop), number of sequences analyzed $(N)$, haplotype diversity $\left(H_{d}\right)$; number of segregating sites $(s)$; number of nucleotide differences per silent sites $\left(\pi_{\mathrm{s}}\right)$, theta per silent sites $\left(\theta_{s}\right)$, Tajima's $\mathrm{D}(D)$.

Table 4. Pairwise $F_{S T}$ between six populations of $S$. sumatrana

\begin{tabular}{llll}
\hline \multicolumn{1}{c}{ Population } & $\begin{array}{c}\text { Pakpak } \\
\text { Bharat }\end{array}$ & Humbahas & $\begin{array}{c}\text { Tapanuli } \\
\text { Utara }\end{array}$ \\
\hline Pakpak Bharat & - & & \\
Humbahas & 0.8022 & - & \\
Tapanuli Utara & 0.8095 & 0.0029 & - \\
\hline
\end{tabular}




\section{Discussion}

Endemic species tend to have a low level of genetic diversity due to their small population sizes (Hamrick and Godt 1989). Therefore, considering the restricted distribution of $S$. sumatrana to only grow in North Sumatra, it was expected that populations would show lower genetic variation than those of wider distribution. However, this study revealed that $S$. sumatrana maintains high genetic variation. This result is congruent with the pattern of other Styrax species that previously studied using different molecular markers. Using AFLP markers, Wang et al. (2015) determined that $S$. obassia possessed high genetic diversity at the species level $(\mathrm{Na}=1.9960, \mathrm{Ne}=$ 1.2782, Nei's gene diversity $\mathrm{H}=0.1764$ ) but no positive correlation between genetic and geographical distance. By using SRAP markers, Nan et al. (2012) showed that $S$. tonkinennsis reflected a high level of genetic diversity and significant genetic differentiation within and among population with also positive correlation between genetic and geographical distance. Iwasaki et al. (2006) studied several deciduous broad-leaved forests and found that $S$. obassia possessed a relatively large number of intraspecific $c p D N A$ variation with the nucleotide diversity value $(\pi)$ of $1 \times 10^{-3}$. Comparing to this species which is endemic to Hokkaido-Japan and China, $S$. sumatrana maintains nucleotide diversity value three times higher $\left(\pi=3.3 \times 10^{-3}\right)$.

During the last glacial period (c. 20,000 years ago), western and northern Sumatra together with northern and eastern Borneo, and the Mentawai Islands existed as rainforest refugia (Thomas 2000; Gathorne-Hardy et al. 2002; Slik et al. 2003). The extant tropical forest in central and eastern Sumatra, therefore, appeared only recently after the last glacial period (no more than 20,000 years ago) and this may be the cause for why the existence of the Styrax sumatrana restricted only to the western coast of North Sumatran Province. The obtained pairwise $F_{S T}$ values are presented in Tables 3. Based on the qualitative guidelines for interpretation of $F_{S T}$ suggested by Wright (1978), a high genetic differentiation was found between Pakpak Bharat and two others population, while low genetic differentiation was found between Humbahas and Tapanuli Utara when both populations shared one similar haplotype, and there are no significant physical barriers among two areas. The differentiated Pakpak Bharat population can be explained by the existence of physical or geographical barriers. The significant Bukit Barisan mountain belt and the occurrence of Samosir Highland may act as a physical barrier altering or hindering gene flow between Pakpak Bharat and the remaining populations. In fact, Hamrick and Godt (2003) stated that the high genetic variation within populations and apparent population structuring between populations showed in this study result are typical of insect-pollinated woody species and indicates that gene flow is localized.

In conclusion, our results showed that each population maintained distinct genetic characteristic, therefore the conservation implication requires the preservation of all population as conservation unit. The strong genetic structuring also indicated how each population differentiated and therefore transferring genetic resources between population in conservation point of view, especially Pakpak Bharat to two others populations, should be avoided.

\section{ACKNOWLEDGEMENTS}

We are indebted to many people who helped with sample collection in the field, particularly Mrs. Cut Rizlani Kholibrina (Forest Research and Development Unit Aek Nauli, North Sumatra, Indonesia). We also grateful to Prof. Iskandar Z. Siregar for letting us use his laboratory for DNA extraction and PCR amplification, Dr. Fifi Gus Dwiyanti for generous help in accommodating the laboratory work. Funding was provided by Joint Research Grant SEAMEO BIOTROP 2016.

\section{REFERENCES}

Battaglia A, Beim E. 2016. Trans-mucosal delivery of a pharmacologically active agent. US Patent US8846092B2

Birky Jr CW. 1995. Uniparental inheritance of mitochondrial and chloroplast genes: mechanisms and evolution. Proc Natl Acad Sci USA 92: 11331-11338

BPS. 2008. North Sumatra in Figures 2008. Badan Pusat Statistik Provinsi Sumatera Utara, Medan. [Indonesia]

Burkill IH. 1935. Styrax. Dictionary of the economic product of the Malay Peninsula II: 2101-2108.

Curran L, Trigg SN, McDonald AK, Astiani D, Hardiono M, Siregar P, Caniago I, Kasischke E. 2004. Lowland forest loss in protected areas of Indonesian Borneo. Science 303: 1000-1003.

Edgar RC. 2004. MUSCLE: multiple sequence alignment with high accuracy and high throughput. Nucleic Acids Res 32 (5): 1792-1797.

Fritsch PW, Boni CC,2 W. Brian S, Alexandra JC, Jennifer KH. 2015. Early phylogenetic divergence of gynodioecious species warrants the recognition of subseries in Styrax series Valvatae. Syst Bot 40 (4): 1081-1092.

Fritsch PW. 2001. Phylogeny and biogeography of the flowering plant genus Styrax (Styracaceae) based on chloroplast DNA restriction sites and DNA sequences of the internal transcribed spacer region. Mol Phylogen Evol 19 (3): 387-408.

Fu YX, Li WH. 1993. Statistical tests of neutrality of mutations. Genetics 133: 693-709.

Fu YX. 1997. Statistical tests of neutrality of mutations against population growth, hitchhiking and background selection. Genetics 147: 915925.

Gathorne-Hardy FJ, Syaukani, Davies RG, Eggleton P, Jones DT. 2002. Quaternary rainforest refugia in Southeast Asia: using termites (Isoptera) as indicators. Biol J Linn Soc 75: 453-466.

Gaveau DLA, Linkie M, Suyadi, Levang P, Leader Wiliams N. 2009. Three decades of deforestation in southwest Sumatra: Effect of coffee prices, law enforcement and rural poverty. Biol Conserv 142: 597605.

Hamrick JL, Godt MJW. 1996. Effects of life history traits on genetic diversity in plant species. Phil Trans Biol Sci 351 (1345): 1291-1298.

Ibrahim S. 2016. Tincture of benzoin to prevent cast slippage in clubfoot. Malays Orthop J 10 (3): 62-63.

Iwasaki T, Aoki K, Seo A, Murakami N. 2006. Intraspecific sequence variation of chloroplast DNA among the component species of deciduous broad-leaved forests in Japan. J Plant Res 119 (5): 539552.

Katz E, Garcia-Fernandez C, Goloubinfoff M. 2002. Sumatran benzoin (Styrax spp). In: Shanley P, Pierce A, Laird S, Guillen A (eds). The management and marketing of NTFPs: Certification as a tool to promote sustainability. Earthscan, London.

Mooventhan P, Manimaran A, Senthil Kumar R, Sathivel A, Selvan, Arul Prakash M. 2016. Indigenous ethnoveterinary medicinal practices for management of mastitis in dairy cattle. Indian J Anim Res 50 (1): 137-139. 
Murray HG, Thompson WF. 1980. Rapid isolation of high molecular weight DNA. Nucleilc Acids Res 8: 4321-4325

Nei M. 1987. Molecular Evolutionary Genetics. Columbia University Press, New York, NY

Olmstead RG, Palmer JD (1994) Chloroplast DNA systematics: a review of methods and data analysis. Amer J Bot 81: 1205-1224

Slik JWF, Poulsen AD, Ashton PS, Cannon CH, Eichhorn KAO, Kartawinata K, Laniari I, Nagamasu M, Van Nieuwstadt MGL, Payne J, Purwaningsih, Saridana, Sidiyasa K, Verburg RW, Webb CO, Wilkie P. 2003. A floristic analysis of the lowland dipterocarp forests of Borneo. J Biogeogr 30: 1517-1531.

Taberlet P, Gielly L, Pautou G, Bouvet J. 1991. Universal primers for amplification of three non-coding regions of chloroplast DNA.Plant Mol Biol 17: 1105-1109.
Tajima F. 1989. Statistical method for testing the neutral mutation hypothesis by DNA polymorphism. Genetics 123: 585-595.

Thomas MF. 2000. Late Quaternary environmental changes and the alluvial record in humid tropical environments. Quaternary Intl 72: 23-36.

Wang, Shi-yan Xing, Li-min Sun, Xiao-jing Liu, Qian-qian Kong. 2015. Genetic diversity of Styrax obassia Sieb. et Zucc. based on AFLP markers. Biochem Syst Ecol 61: 28-34.

Wright S. 1978. Evolution and the genetics of populations, Vol. IV. Variability within and among natural populations. University of Chicago Press, Chicago. 